\title{
Social And Tax Implications Of Planned Giving
}

Naveen Malhotra, Eckerd College, USA

Amanda Smith, Florida Boarderline Personality Disorder Association, USA

\begin{abstract}
Americans have a rich and long history of engaging in philanthropic endeavors, particularly in comparison to other Western nations. Their motivations range from being altruistic and selfsacrificing to wanting to reduce their tax liability before and after death. This paper explores the motivations behind giving as well as the trends surrounding planned giving, including gift annuities, donor-advised funds, and foundations.
\end{abstract}

Keywords: Charitable Giving; Tax Deduction; Social Aspects of Planned Giving; Philanthropy

\section{HISTORY OF PLANNED-GIVING AND TAXATION IN THE UNITED STATES}

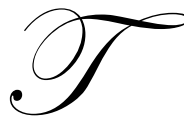

he American tradition of private philanthropy has been established in academic literature. Curti (1958) makes a well-researched case for a history of volunteerism, giving to religious and educational institutions, and the middle-class organization of efforts to alleviate the suffering of fellow citizens to be a part of the "national character" of the United States.

Benjamin Franklin is recognized to be one of the earliest fundraisers in the United States. In his autobiography, Franklin wrote:

It was about this time that another projector, the Rev. Gilbert Tennent, came to me with a request that I would assist him in procuring a subscription for erecting a new meeting-house. It was to be for the use of a congregation he had gathered among the Presbyterians who were originally disciples of Mr. Whitefield. Unwilling to make myself disagreeable to my fellow-citizens by too frequently soliciting their contributions, I absolutely refused. He then desired I would furnish him with a list of the names of persons I knew by experience to be generous and publicspirited. I thought it would be unbecoming in me, after their kind compliance with my solicitations, to mark them out to be worried by other beggars, and therefore refused also to give such a list. He then desired I would at least give him my advice. 'That I will readily do,' said I; 'and, in the first place, I advise you to apply to all those whom you know will give something; next, to those whom you are uncertain whether they will give anything or not, and show them the list of those who have given; and, lastly, do not neglect those who you are sure will give nothing, for in some of them you may be mistaken.' He laughed and thanked me, and said he would take my advice. He did so, for he asked of everybody and he obtained a much larger sum than he expected, with which he erected the capacious and very elegant meeting-house that stands in Arch Street.

America's dedication to volunteerism was noted in the 1830's by French political and economic thinker, Alexis de Tocqueville, in the classic commentary Democracy in America:

The Americans make associations to give entertainments, to found establishments for education, to build inns, to construct churches, to diffuse books, to send missionaries to the antipodes, and in this manner, they found hospitals, prisons, and schools. If it be proposed to advance some truth, or to foster some feeling by the encouragement of a great example, they form a society. Wherever, at the head of some new undertaking, you see the government in France, or a man of rank in England, in the United States you will be sure to find an association. I met with several kinds of associations in America, of which I confess I had no previous notion; and I have often admired the extreme skill with which the inhabitants of the United States succeed in proposing a common object to the exertions of a great many men, and in getting them voluntarily to pursue it. 
While professional fundraising for charitable organizations was still in its infancy in the early $20^{\text {th }}$ century, Congress proposed the Sixteenth Amendment to the constitution. This amendment stated, "The Congress shall have power to lay and collect taxes on incomes, from whatever source derived, without apportionment among the several States, and without regard to any census or enumeration." Just four years later, in 1917, Congress began to allow citizens to deduct gifts to approved charitable organizations from their federal income taxes.

In the United States, an estate tax - also known as an inheritance tax or pejoratively the "death" tax - is imposed on the taxable portion of a deceased person's estate. In the United States, estate tax rates have varied a great deal over the years. However, in 2011, individual taxable estates in excess of \$5 million are taxed at a 35\% rate.

Eisenstein (1956) states that death taxes are ancient taxes. They were known to the Egyptians, as well as the Romans and Greeks. Even the complaints about them have a venerable pedigree.

Kopczuk and Slemrod (2003) observed that:

Evidence from estate-tax returns suggests that some people will themselves to survive a bit longer if it will enrich their heirs. They further remarked, "We cannot rule out that what we have uncovered is not real death elasticity, but instead ex post doctoring of the reported date of death to save on taxes. Even in that case, this exercise provides evidence on how the attempt to collect taxes can engender resource-using avoidance responses that reduce tax revenue.

Tax deductions for charitable donations have been subjected to criticism since their introduction in the tax code. Several arguments assert that the costs involved in tax deductions are not equitable or are insufficient for either the needs of the public or private society. The subsidy theory promotes that the tax-exempt organizations are providing services that are not being adequately offered by either the private market or government agencies. Hence, the tax incentive to the donor is an integral part of accomplishing various societal goals.

Alternatively, a tax-base theory suggests that deductions are allowable simply because a tax has been imposed on income. A third theory - community income - proposes that a more specific exemption replace individual deductions because charities not only help to produce community income, but exist wholly to serve groups of people that come together for a common reason or goal (Buckles 2005).

\section{MOTIVATIONS FOR GIVING: UTILITARIANISM VS. WARM GLOW}

As would be expected, motivations for charitable giving vary greatly.

Sugden (1982) noted that private philanthropy relied on three principal assumptions. The first was a concept of "publicness assumption," and stated that charitable activity occurred, in part, because there was the potential that some public good and utility would be produced. The second assumption was that of "utility maximization." This idea proposed that an individual had a personal objective to maximize his or her utility in giving. The final assumption used Nash conjectures - an aspect of game theory where each player is assumed to know the equilibrium strategies of the other players. In this example, donors would take other philanthropic contributions in charitable activity into consideration.

Sugden (1982) concludes that the generally-accepted idea, even among capitalists, that some government intervention is necessary because private philanthropy is insufficient to meet the needs of society is "paradoxical, implausible, and insistent with empirical evidence."

Karlan and List (2007) explored an aspect of Sugden's utility maximization and Nash conjecture theory in fundraising and found that "The 'supply side' of the economics of charity typically utilizes a model of charitable giving that treats donations no differently from any other consumer purchase. In this view, changes in tax deductibility emulate a change in the price of donating." In their experiment to test cost-benefit analysis, the authors showed that a leadership match of $\$ 1: \$ 1$ ratio was a highly-effective motivator for donors, whereas a larger ratio of $\$ 3: \$ 1$ or $\$ 2: \$ 1$ made no significant difference in giving. 
Other researchers have focused less on the utilitarian aspect of giving and more on altruistic motives of donors. Ribar and Wilhelm (2002) remarked that an important part of utility was derived from a "private joy of giving" or a "warm glow." In discussing fundraising cost, efficiency, and competition, they remarked, "An increase in efficiency reduces the organization's own giving price, raises the implicit price of contributions to 'competitor,' and consequently increases contributions."

While it is generally assumed that wealthier individuals give more, research has shown that giving among individuals with average income stands at a higher percentage of their income regardless of stronger religious affiliation, age, or the cost of giving. Finally, Wiepking (2007) suggests that, "If people earning higher incomes understand how miserly their gifts compare to the donations of those with lower income, it is possible that they will be prepared to donate more substantial amounts."

Donors have a mix of motivations in giving that include altruism and a desire to maximize utility that extends beyond a one-time gift with the perception of a minimum impact. Often a donor wants to help a cause or a group, whose needs are not being currently addressed, by establishing a charitable foundation. The foundation takes care of administration, legal due diligence and regulatory paperwork, while the donor instructs where the money should be donated. An attractive option for wealthier individuals is the visible legacy of a family foundation. A charitable foundation allows the donor to retain control over what gifts are made, to whom, and how often. Such flexibility may be appealing for reasons related to the reduction of tax liability before and after death, as well as the desire for donors to feel like they are maximizing their philanthropic goals.

The Giving USA 2010 study observed that two primary reasons for leaving bequests center on altruistic and strategic themes of "prestige" and a desire to "give back" to an organization that was relevant to the donor during their lifetime. When selecting an organization to support, important donor considerations included the organization's performance and efficiency, followed by the organization's professionalism, quality of programming, and communication methods.

The report also concluded that "Donors are often motivated to include charities in their wills to avoid payment of taxes. However, this study found that the avoidance of taxes through bequest giving was not a primary factor in giving to specific organizations." Households with affluent children who are college educated have a lower probability of having a bequest motive.

\section{CREATING A LEGACY THROUGH GIFT ANNUITIES, DONOR-ADVISED FUNDS, AND FOUNDATIONS}

There is no shortage of investment strategies for Americans with goals of reducing their estate tax liability while creating a legacy. Gift annuities allow a donor to make a substantial gift to a charitable organization today while receiving an annuitized return for the remainder of his or her life.

For donors, the motivations for considering a charitable gift annuity are complex. While many older Americans have a desire to be generous, they are also concerned about their own uncertain economic future. However, the choice of participating in a gift annuity through a favorite charity paying 5 or $6 \%$ can be an astute financial decision in times of low yields in Money Market Funds, Certificates of Deposit, and Savings Accounts.

Although Foundations work well for large bequests, the administrative costs for foundations holding assets of $\$ 10$ million or less can be prohibitive. Donor-advised funds can be the answer, which tend to be more cost effective, though not always.

Donor-advised funds often take the form of a community foundation, allowing an individual to make a taxdeductible gift today with the option of adding to it in the future as a part of their estate plan. While the gift is irrevocable and the donors lose some control over which charities benefit from their gift, the donor's wishes are honored to the best of the fund's ability. Donor-advised funds have experienced explosive growth recently and are likely to become the default choice for planned giving. 


\section{IMPLICATIONS FOR FUTURE PLANNED GIVING}

Ever-changing income and estate tax laws, the state of the economy, a desire to preserve wealth for children and grandchildren and to leave a meaningful legacy to a charitable organization are all determinants in endof-life giving. The Giving USA 2010 report revealed that charitable bequests for 2009 were estimated to reach almost $\$ 24$ billion - a $23.9 \%$ decline from the 2008 estimate. Most recently, tax cuts for the wealthy Americans, the economic recession, and the repeal of the estate tax during 2010 have had widespread implications on estate planning and charitable giving.

Widespread demographic changes are also important to note. James (2009) studied the theory of the upcoming "windfall" and "flood" of gifts that many charitable organizations expected with the "graying" of the American population. He concluded that the estate giving of the wealthy was often diverted from charitable organizations toward private foundations, justifying that total lifetime giving was far greater than gifts received after death. Estate gifts can provide an important cushion to allow nonprofit organizations time to find replacement donors to make up the loss in annual giving. However, estate gifts, by themselves, do not fully make up for the mortality-related loss of annual giving and volunteering. Furthermore, the offsetting opportunity cost is very real, even if the nonprofit eventually recruits new living donors.

James (2009) emphasized that the presence of children or grandchildren played an important role in determining whether a bequest was made to a charitable organization or not. Less than only $10 \%$ of current donors with a will or trust who had grandchildren also included any charitable provision.

When it comes to the goal of creating legacy gifts, individuals have several options that allow them to maximize their donations. Fundraisers and other nonprofit leaders who understand price sensitivity of donations, demographic shifts, and economic changes can respond by providing flexible giving options to meet the needs of donors. Knowledge of an individual's utilitarian and altruistic motives for giving can also help gift-officers better understand potential donors.

\section{AUTHOR INFORMATION}

Dr. Naveen K. Malhotra is the professor of International Business and Finance at Eckerd College. He holds degrees from University of Delhi, University of Tampa, and the University of South Florida. He has widely published in the area of Finance, Lifelong Learning and International Business issues. As the Sam M. Walton Free Enterprise Fellow at Eckerd College, he directs the highly successful Students in Free Enterprise service-learning chapter. His team has repeatedly won its regional and national championships awards and has been widely recognized for its efforts by the City Council and the Mayor of St. Petersburg, Florida.

Amanda L. Smith is the founder of Florida Borderline Personality Disorder Association-a 501(c)(3) organization dedicated to education, support, and advocacy for individuals diagnosed with BPD, their families, and mental health professionals. Previously she served as the executive director for NAMI Pinellas County.

\section{REFERENCES}

1. Buckles, Johnny. (2005). "The Community Income Theory of the Charitable Contribution Deductions." Indiana Law Journal. 80, 947-986.

2. Curti, Merle. (1958). "American Philanthropy and the National Character." American Quarterly.10.4:420437.

3. de Tocqueville, Alexis. Democracy in America. George Lawrence, trans.; J. P. Mayer, ed.; New York: Perennial Classics, 2000.

4. $\quad$ Eisenstein, Louis. (1956). "The Rise and Decline of the Estate Tax." Tax Law Review. 11, 223-259.

5. $\quad$ Franklin, Benjamin. Autobiography and Other Writings. Oxford University Press. 2009.

6. $\quad$ Giving USA Foundation. (2010). Giving USA. Indianapolis, IN.

7. James, Russell. (2009). "Health, Wealth, and Charitable Estate Planning: A Longitudinal Examination of Testamentary Charitable Giving Plans.” Nonprofit and Voluntary Sector Quarterly. 38.6: 1026-1043. 
8. James, Russell. (2009). “The Myth of the Coming Charitable Estate Windfall.” The American Review of Public Administration. 39.6: 661-674.

9. Karlan, Dean and List, John. (2005). "Does Price Matter in Charitable Giving? Evidence from a Large Scale Natural Field Experiment." The American Economic Review. 97.5: 1774-1793.

10. Kopczuk, Wojciech and Slemrod, Joel. (2006). "Dying to Save Taxes: Evidence from Estate-Tax Returns on the Death Elasticity." The Review of Economics and Statistics. 85.2: 256-265.

11. Ribar, David C., and Mark O. Wilhelm. (2002). "Altruistic and Joy-of-Giving Motivations in Charitable Behavior." Journal of Political Economy 110.2: 425-457.

12. Sugden, Robert. (1982). "On the Economics of Philanthropy.” The Economic Journal. 92.6:341-350.

13. Wiepking, Pamela. (2007). "The Philanthropic Poor: In Search of Explanations for the Relative Generosity of Lower Income Households.” Voluntas.18:339-358 
NOTES 